\title{
ГАЛОГЕН-ЗАМЕЩЕННЫЕ ФТАЛОЦИАНИНЫ ЛАНТАНИДОВ: СИНТЕЗ И СОЛЮБИЛИЗАЦИЯ
}

\section{Е.А. Горбунова, Д.А. Степанова, А.В. Сыбачин, М.К. Беклемишев, Т.В. Дубинина}

Химический факультет, МГУ имени М.В. Ломоносова, 119991, Россия, Москва, Ленинские горы, 1.

DOI: 10.19163/MedChemRussia2021-2021-344

E-mail: lena.kuzmina94@gmail.com

Галоген-замещенные фталоцианины лантанидов являются перспективными фотосенсибилизаторами. За счёт эффекта тяжёлого атома (галоген и лантанид) они способны эффективно генерировать $\mathrm{O}_{2}{ }_{2}$. Электроноакцепторные функциональные группы повышают устойчивость комплексов к фотодеградации. Основная проблема низкая растворимость целевых соединений в воде и ДМСО. Улучшить растворимость можно за счет включения гидрофобных фталоцианинов в мицеллы - «наноконтейнеры» на основе полилактидов.

Для получения галогензамещенных фталоцианинов использовали два подхода: темплатный синтез из тетра- и дигалоген-замещенных фталонитрилов и синтез на основе лиганда. Кроме стандартной термической активации использовалась активация темплатной сборки микроволновым излучением, что позволило сократить время синтеза до нескольких минут. При активации лазером $\lambda_{\text {рабоч }}=620$ нм в растворе комплексов лютеция наблюдается генерация как $\mathrm{O}_{2}{ }^{1}$ (метод «химической ловушки»), так и супероксид анион-радикала (NBT в присутствии NADH). По сравнению с незамещенными фталоцианинами лютеция, галоген-замещенные аналоги демонстрируют бо́льшие значения выходов активных форм кислорода.
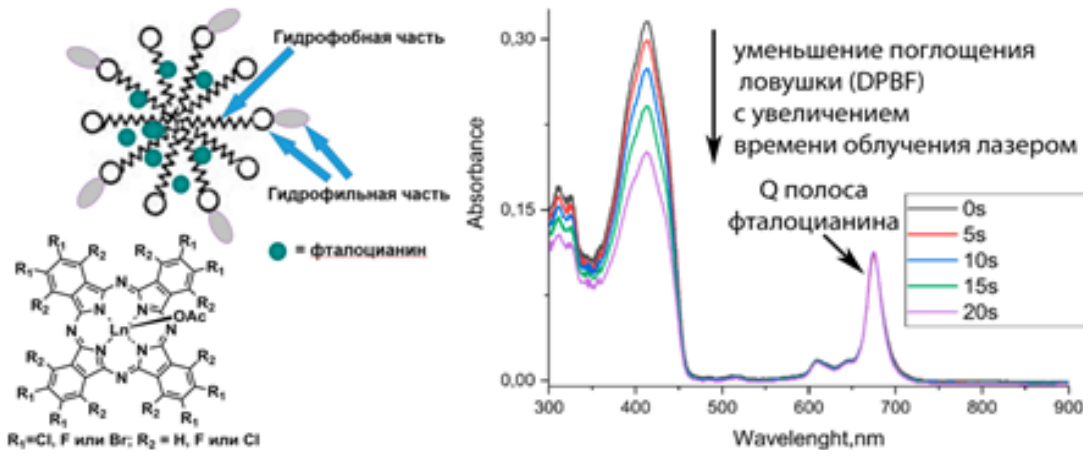

Продемонстрирована возможность включения фталоцианиновых комплексов в мицеллы (5 масс. \%), при этом такие системы демонстрируют устойчивость к ферментативному гидролизу в течение 24 часов, после чего подвергаются биодеструкции. Средний размер полученных мицелл составил 300-315 нм.

Работа выполнена при поддержке грантов РФФИ Аспиранты № 20-33-90157 и 18-53-76006 ЭРА.

$$
-344-
$$

